\title{
A case of hypothalamic hypopituitarism accompanied by recurrent severe hypoglycemia
}

\author{
Maiko Takai, Hideaki Kaneto, Shinji Kamei*, Tomoatsu Mune and Kohei Kaku
}

\begin{abstract}
Introduction: Hypothalamic hypopituitarism is relatively rare cause of secondary adrenal deficiency which is often accompanied by severe hypoglycemia. Hydrocortisone replacement therapy is essential for this condition, but gastrointestinal symptom such as nausea and vomiting is not well-recognized adverse effect of hydrocortisone.

Case description: A 64-year-old-woman was referred to our hospital because of frequent severe hypoglycemia. She was diagnosed as type 2 diabetes when she was 58 years old but had not been treated since she was 60. We ruled out the possibility of exogenous administration of insulin or other anti-diabetic drugs, insulinoma and insulin autoimmune syndrome. After glucose injection, she once became conscious, but severe hypoglycemia was often observed even after that. In addition, counter-regulatory hormone levels were not increased even at the time of hypoglycemia. We conducted several hormone load tests. In corticotropin-releasing hormone (CRH) load test, excess and delayed reaction of ACTH was observed. In thyrotropin-releasing hormone (TRH) load test, TSH and prolactin were normally secreted in response to TRH. In luteinizing hormone-releasing hormone (LHRH) load test, delayed reaction of $\mathrm{LH}$ and FSH was observed. Based on such hormone loading tests, we diagnosed this patient as idiopathic hypothalamic hypopituitarism and consequent adrenal deficiency. We immediately intravenously injected hydrocortisone and started oral hydrocortisone therapy. However, just after taking hydrocortisone, vomiting was often observed which disturbed sufficient steroid hormone replacement, leading to recurrent hypoglycemia. Therefore, we stopped hydrocortisone and instead started an alternative treatment with prednisolone. After that, vomiting and hypoglycemia were not observed at all.

Discussion and Evaluation: We diagnosed this subject as hypothalamic hypopituitarism mainly by the following two findings: (1) excess and delayed reaction of ACTH in CRH load test, (2) delayed reaction of $\mathrm{LH}$ and FSH in LHRH load test.

Conclusions: We should be aware of the possibility of hypothalamic hypopituitarism as a cause of recurrent severe hypoglycemia. Also, we should be aware that hydrocortisone could induce gastrointestinal symptom and that in such a case we should stop hydrocortisone and start prednisolone to sufficiently replace steroid hormone and avoid recurrent hypoglycemia.
\end{abstract}

Keywords: Hypothalamic hypopituitarism; Hypoglycemia; Hydrocortisone

\footnotetext{
* Correspondence: s.kamei@med.kawasaki-m.ac.jp

Division of Diabetes, Metabolism and Endocrinology, Kawasaki Medical School, 577 Matsushima, Kurashiki 701-0192, Japan
} 


\section{Background}

It is well known that hypoglycemia is induced by various reasons such as the overuse of anti-diabetic drugs and/or insulin, various diseases including insulinoma, insulin autoimmune syndrome and adrenal insufficiency. Hypoglycemia influences quality of life and increases the risk of cardiovascular events (Frier et al. 2011; Barendse et al. 2012). When subjects suffer from hypoglycemia, they usually notice it with warning symptoms such as cold sweating and/or palpitation, but recurrent hypoglycemia can lead to the impairment of counter-regulatory hormone response and awareness of hypoglycemia which sometimes leads to life-threatening hypoglycemic coma (Widom and Simonson 1992; Kinsley et al. 1995; Lingenfelser et al. 1995; Kaneto et al. 1998). Hypothalamic hypopituitarism is relative rare cause of adrenal deficiency. Consequent adrenal deficiency is often accompanied by severe hypoglycemia. Hydrocortisone replacement therapy is essential for this condition, but gastrointestinal symptom such as nausea and vomiting is not well-recognized adverse effect of hydrocortisone. Here we report the case of hypothalamic hypopituitarism accompanied by recurrent severe hypoglycemia.

\section{Case report}

Here we report the case of a 64-year-old-woman with hypothalamic hypopituitarism accompanied by recurrent severe hypoglycemia. She was diagnosed as type 2 diabetes in the preoperative examination prior to cataract surgery when she was 58 years old. After then she was treated with insulin for two years, but she did not use any anti-diabetic drugs since she was 60 . Since she had experienced severe hypoglycemia many times, she was referred to our hospital to examine the pathogenesis of severe hypoglycemia. On admission, her body weight was $58.9 \mathrm{~kg}$ and height was $145 \mathrm{~cm}$ (Body Mass Index was $28.0 \mathrm{~kg} / \mathrm{m}^{2}$ ). There was no abnormality in the chest and abdomen and no pretibial pitting edema. She had no history of traumatic head injury. Furthermore, she had no history of risky jobs and the martial arts, especially boxing and full contact Karate. Blood pressure was $155 / 71 \mathrm{mmHg}$ and pulse rate was $88 \mathrm{bpm}$. Neurologic examination showed no abnormality. She did not have visual disturbance and headache. Deep tendon reflex was normal in bilateral lower extremities. Tables 1 and 2 show the laboratory findings on admission. HbA1c was $5.4 \%$, and fasting plasma glucose was $115 \mathrm{mg} / \mathrm{dl}$. Serum insulin level was $1.1 \mu \mathrm{U} / \mathrm{ml}$, and anti-insulin antibody was $3.8 \%$. Electrolytes, whole blood count, renal and liver function were normal (Table 1). In addition, there was no findings that made us suspect any malignancy, auto-immune and/or inflammatory disease (Table 2). Based on these findings, we ruled out the possibility of exogenous administration of insulin or other anti-diabetic
Table 1 Laboratory findings on admission

\begin{tabular}{|c|c|c|c|c|c|}
\hline$\overline{\mathrm{RBC}}$ & $441 \times 10^{4} / \mu \mathrm{l}$ & $\mathrm{TP}$ & $7.4 \mathrm{~g} / \mathrm{dl}$ & CRP & $0.13 \mathrm{mg} / \mathrm{dl}$ \\
\hline $\mathrm{Hb}$ & $13.0 \mathrm{~g} / \mathrm{dl}$ & Alb & $4.3 \mathrm{~g} / \mathrm{dl}$ & Total chol & $169 \mathrm{mg} / \mathrm{dl}$ \\
\hline WBC & $8030 / \mu \mathrm{l}$ & Glb & $3.1 \mathrm{~g} / \mathrm{dl}$ & TG & $102 \mathrm{mg} / \mathrm{dl}$ \\
\hline $\mathrm{Neu}$ & $65.0 \%$ & T-bil & $0.5 \mathrm{mg} / \mathrm{dl}$ & HDL chol & $36 \mathrm{mg} / \mathrm{dl}$ \\
\hline Eos & $5.4 \%$ & AST & $28 \mathrm{IU} / \mathrm{I}$ & LDL chol & $109 \mathrm{mg} / \mathrm{dl}$ \\
\hline Baso & $0.6 \%$ & ALT & $51 \mathrm{IU} / \mathrm{I}$ & FPG & 115 mg/dl \\
\hline Mono & $6.6 \%$ & Y-GTP & $12 \mathrm{IU} / \mathrm{I}$ & $|\mathrm{R}|$ & $1.1 \mu \mathrm{U} / \mathrm{ml}$ \\
\hline Lymph & $22.4 \%$ & $\mathrm{LDH}$ & 496 IU/I & C-peptide & $3.8 \mathrm{ng} / \mathrm{ml}$ \\
\hline plt & $34.6 \times 10^{4} / \mu l$ & ALP & $399 \mathrm{IU} / \mathrm{I}$ & $\mathrm{HbA1c}$ & $5.4 \%$ \\
\hline $\mathrm{Na}$ & $140 \mathrm{mEq} / \mathrm{l}$ & ChE & $35 \mathrm{IU} / \mathrm{I}$ & GA & $12.1 \%$ \\
\hline K & $3.9 \mathrm{mEq} / \mathrm{l}$ & Cre & $0.47 \mathrm{mg} / \mathrm{dl}$ & anti-insulin Ab & $3.8 \%$ \\
\hline $\mathrm{Cl}$ & $103 \mathrm{mEq} / \mathrm{l}$ & BUN & $8 \mathrm{mg} / \mathrm{dl}$ & anti-GAD Ab & $<1.3 \mathrm{U} / \mathrm{ml}$ \\
\hline $\mathrm{Ca}$ & $9.2 \mathrm{mg} / \mathrm{dl}$ & UA & $3.8 \mathrm{mg} / \mathrm{dl}$ & urine protein & $<10 \mathrm{mg} / \mathrm{dl}$ \\
\hline$P$ & $3.2 \mathrm{mg} / \mathrm{dl}$ & Amy & $17 \mathrm{U} / \mathrm{l}$ & urine albumin & $20.3 \mathrm{mg} / \mathrm{gCl}$ \\
\hline
\end{tabular}

drugs, insulinoma and insulin autoimmune syndrome. After glucose injection, she once became conscious, but severe hypoglycemia was often observed even after that. In addition, counter-regulatory hormone levels were not increased even at the time of hypoglycemia (Table 3).

To explore the pathogenesis of severe hypoglycemia, we performed several examination. First, magnetic resonance imaging (MRI) of the brain showed no obvious abnormalities; pituitary abnormality such as adenoma and pituitary stalk interruption was not observed. Second, we conducted several hormone load tests (Figure 1). In corticotropin-releasing hormone $(\mathrm{CRH})$ load test, excess and delayed reaction of ACTH (adrenocorticotropic hormone) was observed, indicating the dysfunction of the hypothalamus. In thyrotropin-releasing hormone (TRH) load test, TSH and prolactin were normally secreted in response to TRH. In luteinizing hormonereleasing hormone (LHRH) load test, delayed reaction of $\mathrm{LH}$ and FSH (follicle stimulating hormone) was observed, which was also compatible with the possible dysfunction of the hypothalamus. Furthermore, in arginine load test, GH reaction was very poor, which strengthened the idea that the hypothalamus in this subject does not function well. Based on these findings, we diagnosed this subject as hypothalamic hypopituitarism although its cause remained unknown. In growth hormone-releasing hormone (GHRH) load test, GH reaction was poor. Although the results in this GHRH load test suggest the possibility of adult GH deficiency, serum IGF-1 (insulin-like growth factor-1) level was within normal range. Therefore, we followed up without any medication for this poor $\mathrm{GH}$ response.

To treat this hypothalamic hypopituitarism and consequent adrenal deficiency, we intravenously injected hydrocortisone $(100 \mathrm{mg})$ and started oral hydrocortisone therapy 
Table 2 Laboratory findings on admission

\begin{tabular}{|c|c|c|c|c|c|}
\hline $\mathrm{ACTH}$ & $29.5 \mathrm{pg} / \mathrm{ml}$ & TSH & $4.19 \mu \mathrm{lU} / \mathrm{ml}$ & CEA & $3.4 \mathrm{ng} / \mathrm{ml}$ \\
\hline cortisol & $8.9 \mu \mathrm{g} / \mathrm{dl}$ & FT3 & $2.92 \mathrm{pg} / \mathrm{ml}$ & CA19-9 & $18 \mathrm{U} / \mathrm{ml}$ \\
\hline plasma renin activity & $1.7 \mathrm{ng} / \mathrm{ml} / \mathrm{h}$ & FT4 & $0.76 \mathrm{ng} / \mathrm{dl}$ & CA125 & $19.9 \mathrm{U} / \mathrm{ml}$ \\
\hline aldosterone & $55.7 \mathrm{pg} / \mathrm{ml}$ & anti-Tg Ab & $25.2 \mathrm{U} / \mathrm{ml}$ & AFP & $3.1 \mathrm{ng} / \mathrm{ml}$ \\
\hline DHEA-S & $123 \mu \mathrm{g} / \mathrm{dl}$ & anti-TPO Ab & $9.6 \mathrm{U} / \mathrm{I}$ & PIVKA-II & $23 \mathrm{mAU} / \mathrm{ml}$ \\
\hline LH & $24.0 \mathrm{mU} / \mathrm{ml}$ & TRAb & $1.6 \mathrm{U} / \mathrm{I}$ & DUPAN & $\leq 25 \mathrm{U} / \mathrm{ml}$ \\
\hline FSH & $66.9 \mathrm{mU} / \mathrm{ml}$ & TSAb & $140 \%$ & SPAN-1 & $7.5 \mathrm{U} / \mathrm{ml}$ \\
\hline PRL & $18.1 \mathrm{ng} / \mathrm{ml}$ & anti-nuclear antibody & $(-)$ & CYFRA & $\leq 1.0 \mathrm{ng} / \mathrm{ml}$ \\
\hline $\mathrm{GH}$ & $0.09 \mathrm{ng} / \mathrm{ml}$ & pituitary cell antibody & $(-)$ & SCC & $0.9 \mathrm{ng} / \mathrm{ml}$ \\
\hline somatomedin C & $114 \mathrm{ng} / \mathrm{ml}$ & $\operatorname{lgG} 4$ & $<3.0 \mathrm{mg} / \mathrm{dl}$ & ProGRP & $46.5 \mathrm{pg} / \mathrm{ml}$ \\
\hline adrenaline & $23 \mathrm{pg} / \mathrm{ml}$ & $1,25-(\mathrm{OH}) 2$ vitamin $\mathrm{D}$ & $63.4 \mathrm{pg} / \mathrm{ml}$ & QFT & $(-)$ \\
\hline noradrenaline & $240 \mathrm{pg} / \mathrm{ml}$ & urine $\mathrm{Na}$ & $42 \mathrm{mEq} / \mathrm{l}$ & $\mathrm{Tb} \mathrm{Ab}$ & $<0.05 \mathrm{U} / \mathrm{ml}$ \\
\hline \multirow[t]{2}{*}{ dopamine } & $15 \mathrm{pg} / \mathrm{ml}$ & urine $\mathrm{K}$ & $13 \mathrm{mEq} / \mathrm{l}$ & ACE & $12.3 \mathrm{U} / \mathrm{I}$ \\
\hline & & & & CMV pp65 Ab & $(-)$ \\
\hline
\end{tabular}

(10 mg/day). However, just after taking hydrocortisone, vomiting was often observed. Since gastrointestinal symptom was not common adverse effect of hydrocortisone, we suspected the acute gastric ulcer and/or gastritis. Then we performed the gastroesophageal endoscopy, but no abnormalities was found. Therefore, we continued to try to replace steroid hormone with hydrocortisone. However, it seemed that such repeated vomiting disturbed sufficient steroid hormone replacement, leading to recurrent hypoglycemia. Several days later, we gave up the therapy with hydrocortisone and instead started an alternative treatment with prednisolone $(15 \mathrm{mg} /$ day $)$ to replace steroid hormone. After that nausea and vomiting disappeared and hypoglycemia was not observed at all.

\section{Discussion and evaluation}

In this report, we showed the subject with hypothalamic hypopituitarism which was diagnosed based on the following findings: excess and delayed reaction of ACTH in

Table 3 Various counter-regulatory hormone levels at the time of hypoglycemia

\begin{tabular}{lll}
\hline PG $(\mathrm{mg} / \mathrm{dl})$ & 42 & 36 \\
$\mathrm{IRI}(\mu \mathrm{U} / \mathrm{ml})$ & $<1.0$ & $<1.0$ \\
C-peptide $(\mathrm{ng} / \mathrm{ml})$ & 0.1 & 0.1 \\
glucagon $(\mathrm{pg} / \mathrm{ml})$ & 75 & 117 \\
ACTH $(\mathrm{pg} / \mathrm{ml})$ & 16.4 & 10.9 \\
cortisol $(\mu \mathrm{g} / \mathrm{dl})$ & 4.6 & 5.6 \\
GH $(\mathrm{ng} / \mathrm{ml})$ & 0.59 & 1.09 \\
adrenaline $(\mathrm{pg} / \mathrm{ml})$ & 40 & 40 \\
noradrenaline $(\mathrm{pg} / \mathrm{ml})$ & 287 & 489 \\
dopamine $(\mathrm{pg} / \mathrm{ml})$ & 17 & 41 \\
\hline
\end{tabular}

$\mathrm{CRH}$ load test, delayed reaction of $\mathrm{LH}$ and $\mathrm{FSH}$ in $\mathrm{LHRH}$ load test, poor $\mathrm{GH}$ reaction in arginine load test. Although we understood that it would be important to perform insulin tolerance test in order to reconfirm the dysfunction of the hypothalamus in this subject, we failed to obtain the agreement from this subject about the insulin load test due to the risk of the occurrence of hypoglycemia. It was reasonable that this subject was very afraid of the occurrence of hypoglycemia because she experienced severe hypoglycemia repeatedly. Therefore, we decided not to perform insulin tolerance test in this subject. The $\mathrm{GH}$ releasing hormone + arginine (GHRH + ARG) test is the best method to accurately evaluate $\mathrm{GH}$ secretion. However, according to the Japanese guideline for adult GH deficiency (The hypothalamic-pituitary dysfunction study group of the Ministry of Health Labour and Welfare, Japan 2009), we performed arginine load test without GHRH. Therefore GH response should be considered as low because of insufficient stimulation of $\mathrm{GH}$ secretion. However, based upon the other various findings, we thought that such recurrent severe hypoglycemia in this subject was presumably due to hypothalamic hypopituitarism.

We ruled out the possibility of malignancy, sarcoidosis, tuberculosis and traumatic injury, all of which could be the reason for hypothalamic hypopituitarism (Sharma and Sharma 1991; Saito et al. 2009; Greco 2012; Glezer and Bronstein 2012), and thus we thought that the hypothalamic hypopituitarism in this subject was idiopathic. In addition, counter-regulatory hormone levels were not increased even at the time of hypoglycemia (Table 3). We think that this was presumably due to recurrent hypoglycemia as previously reported (Widom and Simonson 1992; Kinsley et al. 1995; Lingenfelser et al. 1995; Kaneto et al. 1998). 

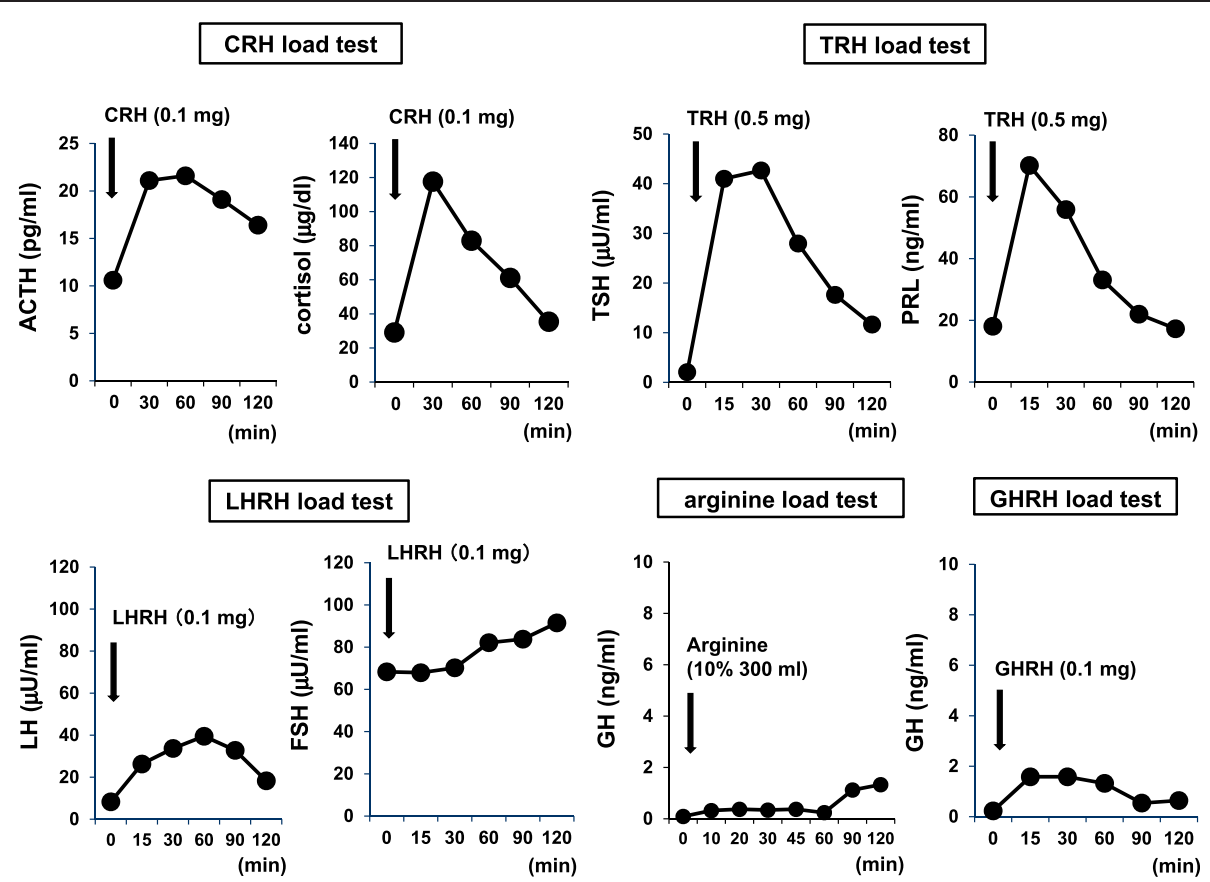

Figure 1 Corticotropin-releasing hormone (CRH) load test: after intravenous injection of CRH $(0.1 \mathrm{mg})$, ACTH and cortisol levels were examined. Thyrotropin-releasing hormone (TRH) load test: after intravenous injection of TRH (0.5 mg), TSH and PRL levels were examined. Luteinizing hormone-releasing hormone (LHRH) load test: after intravenous injection of LHRH (0.1 mg), LH and FSH levels were examined. Arginine load test: after intravenous injection of arginine $(10 \%, 300 \mathrm{ml})$, GH level was examined. Growth hormone releasing hormone (GHRH) load test: after intravenous injection of GHRH (0.1 mg), GH level was examined.

In general, gastrointestinal symptom such as nausea and vomiting is not common adverse effect of hydrocortisone. In addition, prednisolone $(15 \mathrm{mg} /$ day $)$ is stronger than hydrocortisone $(10 \mathrm{mg} /$ day). Therefore, we cannot exclude the possibility that the gastrointestinal symptom in this subject was due to adrenal insufficiency during the hydrocortisone treatment and that the administration of prednisolone improved adrenal insufficiency which led to the disappearance of gastrointestinal symptom. However, considering the situations that nausea and vomiting appeared just after taking hydrocortisone, we think it is likely that such gastrointestinal symptom is the adverse effect of hydrocortisone although its mechanism remains unknown.

\section{Conclusions}

We should be aware of the possibility of hypothalamic hypopituitarism as a cause of recurrent severe hypoglycemia. In addition, although gastrointestinal symptom is not common adverse effect of hydrocortisone, we should be aware that hydrocortisone could induce several gastrointestinal symptom such as nausea and/or vomiting. Such symptom disturbs sufficient steroid hormone replacement and leads to recurrent hypoglycemia. Therefore, in such a case we should stop hydrocortisone and instead start an alternative treatment with prednisolone without any hesitation in order to sufficiently replace steroid hormone and to avoid recurrent hypoglycemia.

\section{Consent}

Informed consent was obtained from this patient for being included in the case report.

\section{Statement of Human and Animal Rights}

All procedures followed were in accordance with the ethical standards of the responsible committee on human experimentation (institutional and national) and with the Helsinki Declaration of 1975, as revised in 2008 (Lingenfelser et al. 1995).

\section{Abbreviations}

RBC: Red blood cell; Hb: Hemoglobin; WBC: White blood cell; Neu: Neutrophil; Eos: Eosinophil; Baso: Basophil; Mono: Monocyte; Lymph: Lymphocyte; plt: Platelet; TP: Total protein; Alb: Albumin; Glb: globulin; T-bil: Total bilirubin; AST: Aspartate transaminase; ALT: Alanine transaminase; $\gamma$-GTP: amma-glutamyl transferase; LDH: Lactate dehydrogenase; ALP: Alkaline Phosphatase; ChE: Cholinesterase; Cre: Creatinine; BUN: Blood urea nitrogen; UA: Uric acid; Amy: Amylase; CRP: C-reactive protein; Total chol: Total cholesterol; TG: Triglyceride; HDL chol: High density lipoprotein cholesterol; LDL chol: Low density lipoprotein cholesterol; FPG: Fasting plasma glucose; IRI: Imunoreactive insulin;

HbA1c: Hemoglobin A1c; GA: Glycoalbumin; anti-GAD Ab: Anti-glutamic acid decarboxylase antibody; ACTH: Adrenocorticotropic hormone; DHEA-

S: Dehydroepiandrosterone sulfate; LH: Luteinizing hormone; FSH: Follicle stimulating hormone; PRL: Prolactin; GH: Growth hormone; IGF-1: Insulin-like growth factor-1; TSH: Thyroid-stimulating hormone; FT3: Free 
triiodothyronine; FT4: Free thyroxine; anti-Tg Ab: Anti-thyroglobulin antibody; anti-TPO Ab: Anti-thyroid peroxydase antibody; TRAb: TSH-receptor autoantibody; TSAb: Thyroid- stimulating autoantibody; IgG4: Immunoglobulin G4; CEA: Carcinoembryonic antigen; CA19-9: Carbohydrate antigen 19-9; CA125: Cancer antigen 125; AFP: Alpha-fetoprotein; PIVKA-ll: Proteins induced by vitamin K absence; DUPAN-2: Duke pancreatic monoclonal antigen type 2; SPan-1: s-pancreas-1 antigen; CYFRA: Cytokeratin fragment; SCC: Squamous cell carcinoma; ProGRP: Pro gastrin-releasing peptide; QFT: QuantiFERON; Tb Ab: tuberculosis antibody; ACE: Angiotensin-converting enzyme; CMV pp65 Ab: Anti-Cytomegalovirus pp65 antibody.

\section{Competing interests}

The authors declare that they have no competing interests.

\section{Authors' contributions}

All authors have contributed significantly and are in agreement with the content of the manuscript. MT and SK are the guarantor of this work and, as such, have full access to all data in the study and take responsibility for the integrity of the data and the accuracy. MT, SK, TM researched data. HK and

KK wrote the manuscript. All authors read and approved the final manuscript.

Received: 16 December 2014 Accepted: 18 March 2015

\section{Published online: 10 April 2015}

\section{References}

Barendse S, Singh H, Frier BM, Speight J (2012) The impact of hypoglycaemia on quality of life and related patient-reported outcomes in type 2 diabetes: a narrative review. Diabet Med 29:293-392

Frier BM, Schernthaner G, Heller SR (2011) Hypoglycemia and cardiovascular risks. Diabetes Care 34:S132-S137

Glezer A, Bronstein MD (2012) Pituitary autoimmune disease: nuances in clinical presentation. Endocrine 42:74-79

Greco DS (2012) Pituitary deficiencies. Top Companion Anim Med 27:2-7 Kaneto H, Ikeda M, Kishimoto M, lida M, Hoshi A, Watarai T, Kubota M, Kajimoto Y, Yamasaki Y, Hori M (1998) Dramatic recovery of counterregulatory hormone response to hypoglycemia after intensive insulin therapy in poorly controlled type 1 diabetes. Diabetologia 41:982-983

Kinsley BT, Widom B, Simonson DC (1995) Differential regulation of counterregulatory hormone secretion and symptoms during hypoglycemia in IDDM. Diabetes Care 18:17-26

Lingenfelser T, Buettner U, Martin J, Tobis M, Renn W, Kaschel R, Jakober B (1995) Improvement of impaired counterregulatory hormone response and symptom perception by short-term avoidance of hypoglycemia in IDDM. Diabetes Care 18:321-325

Saito T, Sato N, Kimoto M, Asano T, Aoki A, Ikoma A, Toyoshima H, Kawakami M, Ishikawa SE (2009) Incomplete deficiency of hypothalamic hormones in hypothalamic hypopituitarism associated with an old traumatic brain injury. Endocr J 56:945-950

Sharma OP, Sharma AM (1991) Sarcoidosis of the nervous system. A clinical approach. Arch Intern Med 151:1317-1321

The hypothalamic-pituitary dysfunction study group of the Ministry of Health Labour and Welfare, Japan (2009) The guideline for the diagnosis and treatment of adult GH deficiency. Available at: http://square.umin.ac.jp/kasuitai/doctor/ guidance.html. Accessed June 20, 2012 (In Japanese).

Widom B, Simonson DC (1992) Intermittent hypoglycemia impairs glucose counterregulation. Diabetes 41:1597-1602

\section{Submit your manuscript to a SpringerOpen ${ }^{\circ}$ journal and benefit from:}

- Convenient online submission

- Rigorous peer review

- Immediate publication on acceptance

- Open access: articles freely available online

- High visibility within the field

- Retaining the copyright to your article

Submit your next manuscript at $\gg$ springeropen.com 